\title{
Spectacular Orientalism: Finding the Human in Puccini's Turandot
}

\author{
Francisca Folch-Couyoumdjian \\ Pontifical Catholic University of Chile, CHILE \\ Faculty of Letters, Santiago
}

Received 17 August 2019 • Revised 30 September 2019 • Accepted 27 October 2019

\begin{abstract}
Giacomo Puccini's final opera, Turandot (1926), remained unfinished at his death, and is often read as a merely orientalist opera in the guise of his Madama Butterfly. I argue, however, that the unnerving search for the human element felt to be missing from the work, suggests a deeper reflection on the state of a devastated Italy in the aftermath of World War I. Turandot's fragmented self-foregrounds the performativity of gender and, ultimately, of the human itself. The libretto's concern with empty characters whose masks hide a terrifying nothingness, as well as the plot point that shows the character of Liù tortured gratuitously on stage, reinforce the idea that, faced with the rise of fascism, the spectacle presented by this opera reveals a disturbing fascination with the alienation of the human, which had dire implications for the value of humanity that would pave the way for another deadly world conflict.
\end{abstract}

Keywords: Puccini, Turandot, spectacular orientalism, human alienation.

\section{Introduction}

It has often been stated that Giacomo Puccini's Turandot (1926) offers a belated echo of the tradition of grand opera. There have been multiple narrative and operatic renditions of the story of the cruel Chinese princess who decapitates her suitors when they fail to answer her questions correctly. At the height of his celebrity, Puccini left his famous version unfinished at his death in 1924. The work was precariously finished by Franco Alfano, and premiered in Milan two years later. In Culture and Imperialism, Said (1994a) criticizes Verdi's Aida as a colonialist fantasy that fetishizes the exotic. Layered with references to the One Thousand and One Nights and based more directly on French and Italian tales, Turandot's multiple transformations into different media similarly respond to this orientalist impulse at the dawn of a Europe shaken to its core by the devastation of World War I. The opera can be read as one extreme view of the orientalized woman: beautiful, barbaric, unattainable, which presents the spectator with a radical alterity; an Orient that, conquered by love, can be rendered innocuous. As reception for the opera shows, however, the main character's ultimate transformation remains unconvincing. Turandot's fragmented, discontinuous self, foregrounds the performativity of gender and, ultimately, of the human itself. In the wake of World War I, and faced with the rise of fascism, the spectacle presented by this opera also seems to reveal a disturbing fascination with the alienation of the human, which had dire implications for the value of humanity that would pave the way for another deadly armed conflict.

(C) Authors. Terms and conditions of Creative Commons Attribution 4.0 International (CC BY 4.0) apply. Correspondence: Francisca Folch-Couyoumdjian, Facultad de Letras, Pontificia Universidad Católica de Chile, Avda.Vicuña Mackenna 486o, Macul, Santiago, CHILE. E-mail: fafolch@uc.cl. 


\subsection{A Swan Song with troubling political connections}

By the time the tale of Turandot reached its definitive operatic form under Puccini's conception, it had undergone several transformations. The libretto was a collaborative effort by Giuseppe Adami and Renato Simoni, who had based their story on Carlo Gozzi's La fiaba cinese teatrale tragicomica (1762), as well as on the German adaptation of Schiller's Turandot, Prinzessin von China: Ein tragikomisches Märchen (1802), in an Italian translation by Andrea Maffei.

The earliest version of the story was from 1710, written by François Pétis de la Croix, and called Histoire du Prince Calaf et de la Princesse de Chine, presumably a Persian counterpart to the One Thousand and One Nights. Pétis de la Croix's narrative, which he claimed to be a translation from the original collection, introduced three enigmas offered by the princess and Calaf's name riddle. Adami and Simoni eliminated most of the secondary elements of these tales, condensing the action into three acts and maintaining the symbolism of the number three, notably for the riddles and the masks.

Before being taken over by Puccini, the legend had already inspired other composers, including Carl Maria von Weber's incidental music for Schiller's play in 1809. Other notable precursors to Puccini were Antonio Bazzini, Puccini's teacher at the Milan Conservatory, who created Turanda (1867), and Ferruccio Busoni, who in 1917 made the first 2oth century version of the opera. Busoni would die four months before Puccini, in 1924, making Turandot a swan song for both.

Giacomo Puccini (1858-1924) was at the height of his international fame when he started the composition of Turandot. Considered to be the only heir to Verdi, his work at the beginning of the twentieth century appeared as the last vestige of genuinely romantic music, and had little to do with the experimental music that had emerged since Debussy and Stravinsky. Since 1910, and after the poor reception of Il Trittico, Puccini had been looking for a new opera topic, and came upon Turandot as a departure from his usual subject matters. Set in imperial China, the opera concerns the fearful princess Turandot, daughter of Emperor Altoum, who has decreed that she will only marry the noble suitor who correctly answers her three riddles. Any mistaken response signifies death, which has given her an understandably unapproachable aura. Prince Calaf solves the puzzles but decides to conquer her heart as well. Despite the fearfully sadistic protagonist, Puccini wrote to long-time collaborator Giuseppi Adami (1974: 274), "the opera will be not only original but moving", signaling that he was looking to create an opera in the usual sentimental vein in which he felt most comfortable working.

The heyday of the Romantic exotic opera was over, however, and Puccini was working within a different context to that in which he had created Madama Butterfly. For Berger (2005: 76), Puccini's "sense of disappointment in Trittico's fortunes mirrored the malaise of Italy after the war," which had resulted in "Six hundred thousand dead soldiers, many, many more maimed and wounded, unemployment, Communist agitation, strikes" for what turned out to be "A slightly better-looking map of Italy". Indeed, the large discontented crowds in Turandot reveal a tense political climate within the opera. DiGaetani (2001: 60) further speculates that given emperor Altoum and Turandot's tyrannical rule, young Prince Calaf appears as a Mussolini-type leader to offer salvation and guidance to the people.

Much has been written about Puccini's relationship to early Mussolini, and though critics attribute an initial attraction to the political figure, it was undoubtedly tinged by the composer's egotistical aspirations. As Osborne (1982: 246) recounts, Puccini “was delighted when Mussolini made him a Senator [in 1922]: perhaps he thought it put him on the same level as Verdi, who had been elected to the first Italian Parliament in 1861". "What do you think of Mussolini?" Puccini wrote to Adami, "I hope he will prove to be the man we need. Good luck to him if he will cleanse and give a little peace to our country!" (1974: 300). Puccini would not live to see the 
devastating consequences of his political affiliation, but the rather chilling rhetoric used in his statement remains deeply disturbing to contemporary readers in the aftermath of World War II. Puccini accepted an honorary membership to the Fascist Party and sought an audience with Mussolini, but by 1924, feeling the imminence of his death, or at least realizing that his health was rapidly deteriorating, he became focused on the composition of his opera, leaving aside any political aspirations (Osborne, 1982: 247). The political context of Italy is nonetheless essential to understand some of the alarming warnings that this opera raises almost unintentionally. In this, the orientalist topic stemming from Romanticism becomes even more perversely opportunistic in that it explores the machine-like human at the safe remove of an orientalist spectacle.

\subsection{Post-Romantic orientalist spectacle}

The orientalist fascination in opera had developed strongly as imperial conflicts arose and the colonial subjects became an important mirror image against which to calibrate and define the European self, especially during the nineteenth century. In Orientalism, Edward Said (1994b) demonstrates that Europe's construction of the Orient as a mysterious and duplicitous "other" functioned as a means of stabilizing and affirming the identity and cultural centrality of the imperial power. The "other", as a "sort of surrogate and even underground self" (1994b: 3) acts as a site where self-projects its fears and desires. During the latter nineteenth century, operas on exotic topics became immensely popular. Egypt saw the premiere of Verdi's Aida in 1871, a few years later, Bizet would stage his controversial Carmen (1875), which upset family values with its seductive appeal, and towards the end of the century, Puccini would imagine Japan in his Madama Butterfly. In Culture and Imperialism, Said (1994a: 131-132) comments on the neutralizing effect of the opera Aida, which for him portrays several ways in which Western society managed to ignore the unpleasant aspects of the colonial encounter: such as "a self-forgetting delight in the use of power-the power to observe, rule, hold, and profit from distant territories and people ... the idea of Western salvation and redemption through its 'civilizing mission.'. . . [and] the exotic [that] replaces the impress of power with the blandishments of curiosity". As many critics have noted, Puccini's Turandot works in a similarly provocative manner. For Berger, "Performances of Turandot are always an event" that is "better left to the power horses"; if it is not as frequently performed as other Puccini operas, it is simply because it "requires grand resources" (2005: 269). Thus, the politics of the production are already embedded in the opera even before one considers the actual content of the performance. Turandot is an opera of excess, part of the 19th century tradition of spectacle. As Berger drolly puts it, it "is simply impossible to overdo this opera, although many have tried" (2005: 268)-and a quick search for images of productions for the opera amply proves his point.

In the 19th century, women were represented in two lights: the virgin and the whore, the saint and the predator. In Puccini's opera, Turandot appears as the perverse, castrating femme fatale, while Liù takes on the role of chaste virgin. For Arnesen (2009),

Puccini's heroines early on developed three conflicting urges in respect to their tenor lovers: the urge to dominate them, to love them, and to redeem them. His heroines expressed these urges more and more intensely as Puccini aged, to such a point that by the time he began composing Turandot, it was impossible for all three urges to be contained in one character. (p. 257)

The solution for Turandot was to split both the soprano and the tenor characters into two people: Liù and Timur, and Turandot and Calaf-two sets of powerful females and imperiled males (Ibid.: 257).

In her book The Asian Mystique, Sheridan Prasso (2005) argues that the West has constructed stereotypical figures of Eastern women, which she classifies into Dragon Ladies and Geisha Girls-Madama Butterfly being the epitome of the latter orientalist fantasy. In this 
Japanese character, it is the kimono and other geisha accoutrements that form part of the iconic exhibition of Japanese femininity, so that clothing builds the character from the outside, as visual fetishism. Turandot, in turn, is the perfect Dragon Lady, with her image also largely focused on surface ornaments-of special note is her fantastically elaborate headdress, which in the Ricordi poster commissioned for the opera premiere, appears as bookended by double dragon heads. There does not seem to be any historical foundation for this prop, which has taken a life of its own to become central to the Turandot look; the more extravagant, the more it seems to capture the spirit of the character-another indication of the general excess expected in the opera.

Many are the scholars who have attempted to track and isolate the musical chinoiserie on display in the opera, which Puccini both borrowed and invented. In his attempt to create this legendary Peking, the composer gathered documentation on instruments and ancient Chinese themes. According to Ashbrook \& Powers (1991), Puccini drew from only two sources for "authentic" Chinese tunes: one was the music box belonging to Baron Fassini, consul of Italy in China. The other was the booklet Chinese Music by J. A. van Aalst (Shanghai, 1884: 94-95), a manuscript kept by the British Museum. Part of this creative orientalizing of the opera included the use of the pentatonic scale, as opposed to the more traditional diatonic scale of seven tones, which provoked an uncanny, estranging effect.

With Turandot, Puccini aspired to create a work of epic proportions, and his use of the music in the grand scale seems closer to the style of Wagner. By setting the action in a remote China, Puccini minimized the realistic effect and heightened the mythical one. DiGaetani notes that the similarity between Turandot's awakening and Brunhilde's, in the last act of Siegfried, was not coincidental, since Wagner had been much on the composer's mind during his last years (2001: 63). However, the emotional zeal that Wagner had with the subject matter, eluded the Italian composer, who even by his own melancholic tendencies, was more than usually pessimistic about his efforts. In December 1922, he wrote to Adami: "I have tried again and again to write the music for the introductory scene of Act II, and cannot. I don't feel comfortable in China" (1974: 302).

In fact, the setting, which felt so inorganic to Puccini, often seems incidental for critics who conceive of the opera as dealing with universal symbols. For Arnesen, "Turandot is a retelling of the Regeneration Myth, which celebrates the endless cycle of life" (2009: 256). Berger states, in similarly grandiose terms, that the duet between Turandot and Calaf "can encapsulate . . . all the hostility that has ever existed between Man and Woman in both their fleshly and cosmic dimensions" (2005: 281). For Berger, it was the very ambitiousness of this Male vs. Female conflict that proved difficult to resolve in a couple of hours, particularly since Puccini insisted on solving it "on his own human terms (as opposed to Wagner's very philosophical exploration of the mystical union of opposites in Tristan and Isolda)" (Ibid.: 77-78).

For Ashbrook and Powers (1991: 13), “Turandot is a 'number' opera in the Great Tradition of Italian Romantic melodrama-or rather, during the course of its long genesis it gradually became one". There are several "reminiscence themes" that tie musical events to recurring characters or events-although not as cohesively united as the Wagnerian Leitmotifbut the fact that the opera remained unfinished and unrevised by Puccini, makes it seem as if "the formal seams are often stitched over" (Ibid.: 14). The effect is that of a mosaic, a pastiche, rather than a unified work. As such, perhaps the historic and political context becomes even more relevant in understanding the opera as a failed mythological creation that reveals instead the complex throbs of a convulsed country. 


\section{Finding the human in Princess Turandot}

When crafting his plot, Puccini rejected archetypical characters in favor of a search for psychological characterization, and told Simoni that he wanted a Turandot seen through the modern mind (Cao, 2004: 7). Indeed, he and his librettists came up with the reasoning behind the Princess' cruel behavior, which is not attributed to her feminine pride, but to the trauma of rape and treason committed against her ancestress Lo-u-ling.

Vocally, the character of Turandot, "written for a soprano of Wagnerian proportions" (Berger, 2005: 268), was a departure from his typical heroines, who usually carried the sincerity, humanity, and sentiment that were the key Italian qualities of his music. Puccini's task was tricky: he needed to make Turandot distant and extraordinary in the first part of the opera, and then convince the audience that by the end she has a change of heart; that she has fallen in love.

The main obstacle that had to be overcome was Turandot's frigidity, of which Puccini was all too aware since it was unlike any woman he had created before. To Simoni he wrote early on: "we must heighten Turandot's amorous passion, which has suffocated for so long beneath the ashes of her great pride" (as cited in Ashbrook \& Powers, 1991: 56-57). The answers to the enigmas: hope, blood, and Turandot's name show this attempt to heighten the passionate side of the roleBusoni's version, for instance, had taken a more philosophical approach with the following answers to the riddles: human intelligence, habit, and art.

The aria "In questa reggia" [In this palace], designed to give psychological depth to the character, offers the backstory of the rape of Turandot's ancestress, to explain why she beheads her suitors, but it is also an excuse used by the Princess to remain unmarried. Significantly, when Calaf correctly answers the riddles, she begs her father to spare her, with a despair that belies more than just wounded pride: "Ah, no! Tua figlia è sacra! / Non puoi donarmi a lui come una schiava / morente di vergogna!” [Ah, no! Your daughter is sacred! / You can't give me to him like a slave / to die of shame], and then addresses the Prince in anguish: "Non sarò tua! No, no, non sarò tua! / Non voglio, non voglio!" [I will not be yours! No, no, I will not be yours! / I don't want to, I don't want to!] (Adami \& Simoni, 2004: 49). Turandot's moving words indicate a general distaste for the subservient status of married women, which speak to the impact that the first wave feminist movement had had, even in Italy. Turandot's desire to retain her vestal purity, like that of a priestess of her own state, can also be read as queer, resisting a heteronormative tradition whereby the princess is awaiting her knight in shining armor to sweep her off her feet. Another way to read her reasoning is founded on stereotypical notions of the East as possessing infinite patience and a long memory-even for matters of revenge. Following the orientalist cliché, Turandot is presented as ageless and eternal.

Puccini made an interesting choice to set up the character. Instead of having her first be heard and then seen, Turandot is first seen and only much later gets to sing. This underlies the idea that Turandot becomes an object of speculation in its double meaning: an enigma and a visual fetish. Illuminated by a ray of light, she appears as inaccessible and sacred. Significantly, Calaf falls in love with this vision. Though moments ago he had cursed her, her appearance-in which she imperiously makes a gesture to execute the Prince of Persia, makes Calaf exclaim: "O divina bellezza, o meraviglia, / o sogno!" [O divine beauty, o marvel / o dream!] (Adami \& Simoni, 2004: 19). The attraction is thus placed along the Eros/Thanatos dichotomy, holding within it a fascination for death-that of others and of himself. To his credit, however superficial, Calaf's love is at least based on an actual body on stage. The heroes of Busoni and Mozart-in The Magic Flute-both fall in love with portraits.

Turandot's change of heart is also within the tradition of folk and fairy tales. Like Sleeping Beauty, she is released by a kiss. Or, reversing genders, it is Beauty's love that frees the Beast. More actively contributing to the atmosphere of the opera is the morbidly erotic Salomé, which Puccini also found an attractive character. Like Salomé, Turandot is referred to as pure; a 
virgin associated to the night. The crowd establishes a parallel between the bloody moon and the ruthless princess: "O esangue, o squallida! / . . . O amante smunta dei morti! / Come aspettano il tuo funereo lume i cimiteri! / Ecco laggiù un barlume!... / Dilaga in cielo la sua luce smorta" [O bloodless, o terrible one / O gaunt lover of the dead! / How the cemeteries await your funereal lights! / Over there a glimmer is spreading its deathly light in the sky] (Adami \& Simoni, 2004: 17). In Wilde's Salomé (1904), the moon plays a vital role as a symbolic representation of the subconscious, irrational fears and desires. The moon portrays the female cycle of madness associated with Salomé's disturbing danger in particular: "Ah! Look at the moon! . . . She has become red as blood!" (p. 62). Salomé's request for Iokanaan's head is sinister because it is made almost playfully, as if by a child who is not fully aware of her powers of seduction. Although Turandot is aware of her power, like Salomé, she retains a child-like aura that tinges her dreadful requests with innocence. The "Moo-Lee-Vha" theme, taken from the music box, is first enunciated by the choir of children, but is traditionally linked to Turandot. The Princess appears on the balcony of the royal palace, while the chorus repeats "Principessa!" to the same notes they had cried out in their previous climax, summoning the executioner. Symbolically, the innocence of the tune in the angelical voices of the children is tainted with bloodlust, in the same way that Turandot wishes to remain childlike, refusing to embrace the erotic implications of becoming a woman. In Huysmans's $\grave{A}$ Rebours, the decadent antihero Des Esseintes sees symbolist painter Gustave Moureau's pictures of Salomé, and describes her as the "symbolic incarnation of world-old vice"; "a great Beast of the Apocalypse, indifferent, irresponsible, insensible, poisoning" (chap. 5); a character that represents the fin de siècle decadence and death wish. Although composed in the 2oth century, the spirit of Turandot is still tied to the sensibilities of the previous century, and it is not difficult to read in it a similar anxiousness to the one that Salomé portrays regarding the outcome of the struggle between the old generation and the new one, which is particularly significant in the context of the Italian post-war.

One of Puccini's significant changes was to make all the action take place in exterior settings. This made him particularly sensitive to lighting issues, for which he included detailed instructions in his libretto. Setting the scene outside also meant that, as in Aida-which Puccini surely had in mind-, the set designs would be imposing, and present archetypes of order and power. Within this symbolic realm, Turandot is the nocturnal force, while Calaf is clearly associated with the sun. The dawn at the end of the opera brings saving love for Turandot: " $\mathrm{E}$ l'alba! E l'alba! / E amor, e amor nasce col sole!" [It is dawn! It is dawn! / It is love, and love is born with the sun!] (Adami and Simoni, 2004: 65), cries an exultant Calaf upon Turandot's transformation. The heavy-handed symbolism is reminiscent of the binary light-darkness imagery of Mozart's The Magic Flute, in which the evil Queen of the Night is vanquished by Sarastro, the wise, sun-drenched high priest.

Interestingly, in stage productions, Turandot consistently departs from this malefemale dichotomy by presenting the main character as a rather masculine figure or, at the very least, one with androgynous qualities. This contrasts both with Calaf's softer features, and with the feminized body of the Prince of Persia, who raises tender ecstasy in the crowd: "come è dolce il suo volto!" [What a sweet face he has!] (Adami \& Simoni, 2004: 19). More radically, one might argue that the Prince of Persia is a figure that is unequivocally human, while Turandot's cold, and initially mute demeanor, suggests a remote inhumanity.

Turandot sings for the first time after 250 pages of score, with expectations having built throughout the first half of the opera. Her breaking of the silence begins with a recitative, then an arioso, which slowly takes on a more lyrical dimension. Her extended intervention, however, is still devoid of the characteristically Puccinian melodic line, which audiences could not help but perceive as a sign of her inhumanity.

The trouble is that, given that Turandot is the title character, the lack of passion pervades the whole of the opera as a center of reference that remains empty. The composer 
expressed his uneasiness repeatedly to Adami: "I am afraid that Turandot will never be finished. It is impossible to work like this. When the fever abates it ends by disappearing, and without fever there is no creation" (1974: 278).

Puccini remained dissatisfied with his librettists' drafts for the final act. They still had not finished the final text in the autumn of 1924 when his throat cancer was discovered. In early November, he underwent surgery, and on the $29^{\text {th }}$, died of a heart attack, leaving his work unfinished. His final notes on the score famously read "Poi Tristano" [Then, Tristan]-a reference to his hope of having the love duet aspire to the level of Wagner.

Puccini described the great duet that was to end the opera as the encounter of "two almost superhuman beings [which] descend through love to the level of mankind" (Adami, 1974: 321), from which we can gather that Calaf is understood to be Turandot's masculine double. His singing, however, is more conventionally lyrical-as can be seen in what is perhaps the oddest section of the opera, the famous "Nessun dorma" [No one must sleep] aria, which exemplifies the old-fashioned "number opera" of the work, but is also his saving grace as a humanizing element. Turandot has no equivalent to this, although her final aria-composed by Alfano, and often cutis supposed to present just this transitional vehicle of psychological development. Although Calaf shows himself as incorruptible and does not give in to the minister's supplications and bribesthus matching Turandot's purity-he is also unmoved by the spilled blood of previous suitors and of Liù herself. Both Calaf and Turandot wield this purity as part of their integrity, but the fact that the preservation of their bodies comes at the price of Liù's death and the severed heads of suitors, has unsettling implications. The purity of race, the cult of the strong, and the dispensability of weaker human life for transcendental motives-like the love of an ideal-was already an important aspect of futurist art at the time and would become more prevalent in Mussolini's agenda as a way of exalting the wounded pride of Italy.

On the day of Puccini's death, Mussolini issued a statement on behalf of the Italian government: "I wish to remind you in this moment that a few months ago this renowned musician requested admission to the National Fascist Party. He wished to express with this gesture his adherence to a movement which is being discussed, which is being disputed, which is disputable, but which is the only living thing today in Italy" (Osborne, 1982: 250). The notion that the Fascist Party was the only living thing in Italy, is troublingly insightful in light of the issues brought up by the opera of the survival of the strongest. The result of Puccini's death was that the opera took on a symbolic relevance beyond any the composer might have intended.

Toscanini, with whom Puccini had left things on a bad note, felt compelled to take it upon himself to arrange for the premiere of the opera, and finally requested the respected but unremarkable composer Franco Alfano to finish the work. The highly anticipated premiere was attended by the best of the elite and no expenses were spared for the production. Mussolini refrained from attending the event only because the staunchly anti-Fascist Toscanini refused to conduct the Fascist hymn in his honor (Wilson, 2007: 193). The night of the premiere, at La Scala de Milan, two years after Puccini's death, Toscanini, who was conducting, lowered the baton after Liù's death to address audience: "Here concludes the work of the maestro. Here he died." Alfano's ending was only played at the second performance. In contrast with the disastrous reception of Butterfly, "the Turandot premiere was characterised by a reverential, quasi-religious mood," in which critics did not really focus on the music, but rather on the composer's legacy (Wilson, 2007: 194).

It is of course idle speculation to think what the composer might have written had he been able to finish the opera. As Berger states: "One thing is clear: the transformation that Puccini wanted, with Turandot becoming an actual human being, never happens" (2005: 287) - and in this respect critics unanimously agree. 


\section{Empty masks in Turandot}

As Wilson succinctly puts it, "Rather than bearing his soul, as the critics expected him to do in his final opera, Puccini seemed to have concealed genuine feeling behind a number of deceitful masks" (2007: 203). The whole opera was sometimes perceived as purely ornamental, a criticism that had already been aimed at Madama Butterfly.

The motif of masks was literally present in the opera through the use of commedia dell'arte characters. Gozzi's play had reverted to this Italian tradition and included the familiar clowns in legendary China, a device that Puccini decided to keep, replacing the Venetian characters with three Chinese ministers, Ping, Pong and Pang-a percussive onomatopoeia of bland racist connotations. Despite the obvious stereotypes, Puccini seems to have conceived them as characters who would "introduce a touch of our life and, above all, of sincerity" (Adami, 1974: 272). In the long line of critics who desperately try to locate the human element in the opera, Berger (2005: 268) states that the trio "ironically, form the most human core of the work".

On a smaller scale, the masques of the opera can be seen as a Greek chorus, commenting on the action and offering a point of connection with the audience. The three advisors, who are presumably comic figures, appear unmoved and mocking towards Liù, but upon her death, Pong exclaims: "Svegliato s'è qui dentro il vecchio ordigno, / il cuore, e mi tormenta!" [This old mechanism, the heart, has awoken inside me, and is tormenting me!] (Adami \& Simoni, 2004: 62). The metaphor intriguingly presents Pong as a machine, initially devoid of human emotions. The suggestion is that Pong-and presumably all the masks-are somehow alien to humanity, or have become so through their job, that asks them to retain critical distance from peers.

In what turns out to be a more insightful remark than the advisors might have intended, Pang and Ping tell Calaf in Act I, "Turandot non esiste! . . . Non esiste che il Niente, / nel quale ti annulli!” [Turandot does not exist! . . . Only the Nothingness exists / in which you annihilate yourself!] (Adami \& Simoni, 2004: 27). What is supposed to be a philosophical quip of vaguely Taoist implications is in fact deadly accurate in the context of the opera, as critics unfailingly point out. Vittorio Gui asks: "How can one think of taking a character as grotesque and absurdly fictitious seriously? ... As a ludicrous symbol of female frigidity, combined with physical beauty, she might have existed; as a living woman, never" (as cited in Wilson, 2007: 212).

Wilson's interesting study on modernism in Puccini explores the idea that the composer might have been consciously experimenting in his use of a "mechanical" Turandot, since marionette-like figures were omnipresent in the late 1910 s and early 1920 s in Europe. The theory expounding the superiority of the marionette over the actor had been famously portrayed in Kleist's Über das Marionettentheater (1992), which had ironically proposed in 1810 that "Grace appears purest in that human form which has either no consciousness or an infinite one, that is, in a puppet or a god" (p. 244). The concept of the union between man and machine lay at the heart of the Futurist aesthetic and, although at odds with Puccini's own artistic inclinations, must have been felt in the artistic atmosphere of the time-as well as in the political one, given Mussolini's fascination with machines. The use of puppet-like figures was a way to draw attention to the illusory nature of performativity in order to express modernist preoccupations such as "the falseness of contemporary society, the perceived loss of the individual in the modern faceless crowed, the implications of a post-Nietzschean godless world and (in Italy at least) concern about the 'machinations' of an increasingly autocratic state" (Wilson, 2007: 205-206).

Indeed, one of the elements that is still relevant in performances of Turandot is the way in which the main character is actualized to foreground the performativity of its identity, especially in terms of gender. Turandot's larger than life persona is reinforced in her costume: extremely long fingernails, extravagant headdress, and the layers of makeup used to make the usually Western leads into Asian women. Often, the effect is of an uncanny mask; the pronounced 
features seem parodic and make the performer look like a drag-queen, an effect that is ubiquitous in the campy look of this role. Turandot becomes otherworldly; a flashy ornamental item for the empire that men wish to acquire-and the costume choices usually make it impossible to believe in her as a human character, such is the strength of her decorative façade.

\section{Liù, the scapegoat for humanity}

The fact that Liù garners all the sympathy of the opera, as contemporary commentators unfailingly noticed, has repeatedly been used as the main reason for the opera's failure. The problem that arose was that of continuing the opera after Liù's "little, mangled body . . . disappeared behind the scenes," as Gaetano Cesari described at the premiere of the work (Osborne, 1982: 263). Liù's death is by no means exceptional, and follows the line of the traditional Asian scapegoats, most famously Puccini's own Madama Butterfly; the difference is that Liù is not supposed to be the protagonist, but her death effectively signals the end of the opera's heart-as well as the end of Puccini's conception of the opera.

Pétis de la Croix's original tale included the character of Adelmuc, Turandot's slave, who is in love with Calaf and divulges his name out of jealousy. But after the princess saves Calaf, the slave kills herself. In Gozzi, the rival is called Adelpa, an ancient princess turned slave. When she tries to kills herself, Calaf manages to hinder her, and once freed by Turandot, she goes back to her throne. Puccini was familiar with both versions, and even though he did not incorporate these plot points, as a character, Liù seems equally pervaded by death: when Calaf asks her who she is, her submissive response, which effaces her identity, "Nulla sono... una schiava, mio Signore," [I'm no one... a slave, my Lord], is interrupted by the chorus which, sharpening the stone for the executioner, chants "Gira la cote!" [Turn the whetstone!] (Adami \& Simoni, 2004: 15). Ironically, it is not Liù who best fits this description of being "no one," but rather Turandot herself, as bearer of a mask.

It is Puccini's original touch of harmonizing the pentatonic with the classical scale in Liù's first aria, "Signore ascolta" [My Lord, listen], which has been pinpointed by some critics as establishing "Liù as the most genuine human being in the opera" (Berger, 2005: 276). The general perception of contemporary critics was that, up to Liù's death, Puccini had remained true to himself.

Interestingly, Liù is not devoid of criticism, and has also been viewed as a puppet of feigned sentimentality, of which modernist artists were increasingly contemptuous, given that by the 1920s, this sentiment occupied an uneasy position in Italian theatre as part of the Fascist cultural policy to appeal to the "irrational instincts of the masses" (Wilson, 2007: 217). Wilson thus argues that Liù might have been "created especially to indulge Puccini's most sentimental and anachronistic side" (Ibid.: 218). If one examines Liù's gratuitous torture scene that takes place on stage, the argument could be taken one step further.

Although torture was not unfamiliar in the Puccini canon-Tosca must listen to the extended and painful cross-examination of her beloved Mario off stage-the violence to Liù's body is even more gruesome, since it happens in plain sight of viewers. The breach of traditional decorum might reveal how much public sensibilities had altered or hardened at the explicit horrors of World War I. Given the usually stylized deaths in opera, and the fruitless resolution of this torture, one might argue that Puccini seems to reveal a somewhat fetishistic delight in torture. Berger emphasizes that "nearly all the commentators have complained that the onstage torture of Liù was totally unnecessary, and they're right" (2005: 285). For Puccini, torture seems to have functioned as a mechanism to drive home the emotional power of the story, as he wrote to Adami: "I think Liù must be sacrificed to some sorrow, but I don't see how to do this unless we make her 
die under torture. And why not? Her death could help to soften the heart of the Princess..." (1974: 300).

In her study on torture, Elaine Scarry (1985: 31) examines the relationship between pain and death, stating that "The two are the most intense forms of negation, the purest expressions of the anti-human, of annihilation, of total aversiveness, though one is an absence and the other a felt presence". Liù will experience both in close consecutive order. Discussing the relationship between pain and interrogation, Scarry maintains that "the translation of pain into power is ultimately a transformation of body into voice, a transformation arising in part out of the dissonance of the two, in part out of the consonance of the two" (Ibid.: 45). In Liù's case, the power of the voice is absolute, since she is required to sing her confession. Ultimately, however, she remains silent and it is her body carried off stage that gives the emotional power to the scene.

The breadth that torture tries to reach by means of one act is explained by Scarry as follows: "In torture, the individual stands for "individuals" (Ibid.: 62). Much like the Prince of Persia represents the body of many suitors, Liù represents the agony and discontent of the whole crowd: even if she stands in opposition to them, she is the scapegoat for the anger that Turandot directs at the people.

Both Liù and Turandot acquire supernatural qualities in the eyes of the crowd. The people of "Pekino" are terrified of Turandot-"L'insonne non perdona!" [The sleepless one does not forgive] (Adami \& Simoni, 2004: 55)-Turandot is thus a sort of vampiric creature that does not follow normal human biological cycles. Similarly, upon hearing Timur's threat of how "l'anima offesa si vendicherà!” [the offended spirit will seek revenge!], the people are filled with the superstitious fear that, as Arnesen puts it, "Liù, having died unjustly, might return as a vampire, and prey upon them" (2009: 277). If Liù, who represents humanity, sacrifices herself for Turandot to transform her, then she represents a redeeming figure, but if Turandot fails to be transformed, then it is humanity itself that has perished at the altar of this empty figure. On stage, there is no other human left and the fear that emerges is that humanity can only come back as a revenant. At a structural level, the opera can be described in a similar way, since it comes to life again as an echo from a dead past, stitched together post mortem. The fact that the opera that marks the end of the great tradition ironically has no ending, is symbolically appropriate as a vampiric figure who cannot be properly laid to rest.

\section{Conclusions}

One contemporary reviewer wrote-in what turned out to be a typical response to the opera-that "more than a character, [Turandot] is a mask underneath which one feels emptiness and inconsistency" (Antonio Capri, as cited in Wilson, 2007: 196). For Wilson, the hostile reception towards Turandot "can be viewed as encapsulating their anxieties about the social and aesthetic implication of the apparent decline of the human in a machine age" (Ibid.: 196).

The lurking aporetic gap of the opera seems to me one of the reasons why so many contemporary productions have felt free to reconceptualize it. Setting it as a sadomasochistic dungeon-with Turandot as an androgynous figure in black with whip-like strands standing on her head, as in the design by Nikolaus Lehnhoff for the Amsterdam Opera in 2001-or contextualizing it as a Japanese anime, like at Berlin Staatsoper in 2003, current productions like to take risks. If Madama Butterfly productions tend to consistently respect the original Japanese setting, Turandot versions go out of their way to be outrageous and excessive, perhaps to fill that void felt by the lack of emotional center.

It quickly becomes clear that, in an attempt to create a figure of orientalized enticements, Puccini tapped into a crucial contemporary anxiety. The imperial aspirations of the golden age of colonial empire seemed outdated, and Puccini himself was unable to summon its 
ghost. Although the fascination with the oriental would persist in the 2oth century-which partly explains the success of the Ballet Russes, for instance-the straightforward oriental fantasy was no longer sustainable. The concept of what was the human and how it was to be defined, on the other hand, was of the utmost relevance, especially after the human loss in WWI and the cleansing racial concerns of Fascist regimes.

\section{Acknowledgements}

This research did not receive any specific grant from funding agencies in the public commercial, or not-for-profit sectors.

The author declares no competing interests.

\section{References}

Adami, G. (Ed.) (1974). Letters of Giacomo Puccini: Mainly connected with the composition and production of his operas. (E. Makin, Trans.). London: Harrap.

Adami, G., \& Simoni, R. (2004). Turandot libretto. Turandot: L'Avant-Scène Opéra. N. 220. Paris: Éditions Premières Loges, 2004. 5-68.

Arnesen, I. J. (2009). The romantic world of Puccini: A new critical appraisal of the operas. Jefferson, NC: McFarland \& Company, Inc., Publishers.

Ashbrook, W., \& Powers, H. (1991). Puccini's Turandot: The end of the great tradition. Princeton: Princeton UP.

Berger, W. (2005). Puccini without excuses: A refreshing reassessment of the world's most popular composer. New York: Vintage Books.

Cao, H. (2004). Turandot: Literary and musical commentary. Turandot: L'Avant-Scène Opéra, 22O, 5-68.

DiGaetani, J. L. (2001). Puccini the thinker: The composer's intellectual and dramatic development. New York: Peter Lang.

Huysmans, J. K. (1969). Against the grain (À Rebours). (Unknown Trans.). New York: Dover Editions. Retrieved from http://www.ibiblio.org/eldritch/jkh/rebours.html (Original work published 1884).

Kleist, H. v. (1992). On the marionette theater. (Christian-Albrecht Gollub, Trans.). In A. Leslie Wilson (Ed.), German Romantic Criticism (pp. 238-244). New York: Continuum Publishing Company. (Original work published 1810).

Osborne, C. (1982). The complete operas of Puccini: A critical guide. New York: Atheneum.

Prasso, S. (2005). The Asian mystique. New York: Public Affairs.

Said, E. (1994a). Culture and imperialism. New York: Vintage Books.

Said, E. (1994b). Orientalism. New York: Vintage Books, 1994.

Scarry, E. (1985). The body in pain: The making and unmaking of the world. New York: Oxford UP.

Wilde, O. (1904). Salomé. London: Melmoth \& Co.

Wilson, A. (2007). The Puccini problem: Opera, nationalism and modernity. Cambridge: Cambridge UP. 
F. Folch-Couyoumdjian - Spectacular Orientalism: Finding the Human in Puccini's Turandot

C O A $\mathrm{s}$ 